\title{
Correction to: The logic of hatred and its social and historical expressions: From the great witch-hunt to terror and present-day djihadism
}

\section{Jean Greisch ${ }^{1}$}

Published online: 7 May 2020

(c) Springer Nature B.V. 2020

\section{Correction to: Continental Philosophy Review https://doi.org/10.1007/s11007-019-09481-w}

The article "The logic of hatred and its social and historical expressions: From the great witch-hunt to terror and present-day djihadism," written by Jean Greisch, was originally published electronically on the publisher's Internet portal (currently SpringerLink) on March 2020 with open access. With the decision of the author(s) to step back from Open Choice, the copyright of the article changed on April 2020 to (C) Springer Nature B.V. 2020 and the article is forthwith distributed under the terms of copyright.

Publisher's Note Springer Nature remains neutral with regard to jurisdictional claims in published maps and institutional affiliations.

The original article can be found online at https://doi.org/10.1007/s11007-019-09481-w.

Jean Greisch

greisch@wanadoo.fr

1 Institut Catholique de Paris, Paris, France 